\title{
How Do German SMEs Cope with the Increasing Need for Flexibility?
}

\section{Katharina Roitzsch, Winfried Hacker, Ulrike Pietrzyk, and Uwe Debitz}

Workgroup "Thinking-Knowing-Acting", Department of Psychology,

Technische Universität Dresden, Germany

Correspondence should be addressed to Ulrike Pietrzyk, ulrike.pietrzyk@tu-dresden.de

Received 2 March 2012; Accepted 23 May 2012

Academic Editor: Günther Schuh

Copyright (C) 2012 Katharina Roitzsch et al. This is an open access article distributed under the Creative Commons Attribution License, which permits unrestricted use, distribution, and reproduction in any medium, provided the original work is properly cited.

Within this study a qualitative approach was chosen to find out whether German SMEs deal with flexibility requirements rather strategically or intuitively. Results show that many SMEs do not show strategic approaches. Possible reasons are seen in lacking organizational resources as well as the limited training of the CEOs. A toolbox has been developed to offer applicable information about flexibility measures on a low level.

\section{Introduction}

For several years the globalized economic system increased the requirements small and medium-sized enterprises (SMEs) have to cope with [1]. While big companies have departments of change management, of human resource management, and of production planning, SMEs do not have these resources. Nevertheless, they have to deal with these issues, too: manpower shortage, irregular order situations, or customer demands that become more and more individualized. For example, as early as 2007 , about $12 \%$ of companies anticipated problems regarding restaffing [2] and the German employment agency registered more vacant apprenticeship positions than applicants for the current term [3]. Given the lower attractiveness of SMEs compared to big companies [4], the lack of trainees and the higher turnover rate of employees may add to the shortage in well-trained personnel. Moreover Müller [5] stated that German SMEs expect growing product diversity and more urgent orders but at the same time decreasing cycle times. This means that in the future higher needs for flexibility have to be coped with using the same or fewer resources. 


\subsection{The Importance of SMEs for the German Economy}

99,5\% of all German businesses are SMEs according to the EU definition of 2005. Concerning the number of employees, SMEs form the heart of the German economy, too: 55,1\% of the 25 million German employees were employed in SMEs in 2009 [6].

Even during the eurocrisis, SMEs are crucial for Germany's lasting economic stability. Whereas the business climate in the more export oriented big companies showed only a slight increase lately, SMEs, which focus on the domestic market, are still stable and growing. Thus, they are an important pillar of the economic climate in Germany in 2012 [7].

\subsection{Stability through Flexibility}

Voigt and Saatmann [8] define flexibility as "[… the ability of a system (company or network) to deal with changes-induced internally or externally-in a self-reliant, proactive or reactive way to achieve the previous aims. Another possibility is the self-reliant adaption of the goal system as to future or already occurred changes". Hitt et al. [9] add the criterion of competitive advantage.

In contrast, stability is defined as a "feature of a $[\cdots]$ system that enables itself to cope with external influences that disturb its balance and to come back to its initial state or to actively use restoring forces" [10].

Thus, flexibility is an important condition for companies to keep a stable market position and ensure the organisation's survival dealing with obstacles such as irregular order situations and manpower shortage.

The literature distinguishes between several kinds of flexibility that can be seen as being associated with different goal dimensions. This is shown in Table 1 . The stability of several aspects, for example, the order situation, is an important goal of efforts to be flexible and should not be ignored.

\subsection{Strategic Flexibilisation and Change Management}

Strategies can be defined as "rationally planned, consistent bundle of fundamental decisions or measures taken by the management to achieve a companies' long-term aims" [11]. These measures contain reactive as well as proactive ones aiming at the companies' goals, which have to be formulated in advance. The long-term perspective of strategies requires the anticipation of future developments, both inside and outside of the company. The measures should allow the achievement of organisational goals even in changing circumstances, thus granting stability of the entire company.

However, the measures often change organizational structures, processes, forms of contracts, and working schedules. These changes in particular may be perceived as a source of uncertainty by the employees according to Boch and Constanzo [12]. This may affect the working climate, performance, creativity, and the employees' commitment [13, 14]. According to Stahl [15], change management is the most important and most difficult task of companies aiming at balancing stability and flexibility [16]. Change management needs to create readiness for change in the organisation, to reduce resistance and to integrate the employees into the process of change, so that flexibility becomes an inherent part of the organisation without being a threat to the employees [17]. 
Table 1: Types and goals concerning flexibility.

\begin{tabular}{|c|c|c|}
\hline Goal dimension & Explanation & Example \\
\hline Flexibility of delivery & $\begin{array}{l}\text { Delivering the desired product quickly and reliably is } \\
\text { seen as most important. This is most relevant for } \\
\text { products and services of minor complexity [18]. }\end{array}$ & Mass production \\
\hline Flexibility of models & $\begin{array}{l}\text { Different models of the same product are produced or } \\
\text { the product is tailored to the needs of the individual } \\
\text { customer. The flexibility of models is seen as an } \\
\text { especially important goal when products and services } \\
\text { are very complex or if they are designed specifically for } \\
\text { the individual customer [18]. }\end{array}$ & Automobile industry \\
\hline $\begin{array}{l}\text { Flexibility of structures } \\
\text { and processes }\end{array}$ & $\begin{array}{l}\text { Flexibilisation in this area usually has the goal of being } \\
\text { able to react to demands more quickly and to speed up } \\
\text { the entire transaction [19]. }\end{array}$ & $\begin{array}{l}\text { Implementation of } \\
\text { profit centers }\end{array}$ \\
\hline $\begin{array}{l}\text { Flexibility as a key } \\
\text { qualification of } \\
\text { employees }\end{array}$ & $\begin{array}{l}\text { This dimension contains three aspects: } \\
\text { (i) The ability to cope with complex problems and } \\
\text { unintended situations } \\
\text { (ii) Job related and geographic mobility as well as } \\
\text { (iii) The availability of the employee to his or her } \\
\text { employer at all times }\end{array}$ & $\begin{array}{l}\text { Solving of arising } \\
\text { problems, } \\
\text { field work, } \\
\text { "blackberry culture" }\end{array}$ \\
\hline Flexibility of employees & $\begin{array}{l}\text { The internal flexibilisation in particular has been } \\
\text { shown to be related to positive consequences for the } \\
\text { employees. Keywords concerning this are for example } \\
\text { conveyment of responsibility, scope of action, use of } \\
\text { skills or self-organization [20]. As a way of keeping } \\
\text { qualified employees in the company, this could be a } \\
\text { goal of the employer. }\end{array}$ & Flexitime \\
\hline Managerial Flexibility & $\begin{array}{l}\text { This means a change in regulations concerning the } \\
\text { work and contract conditions, for example by } \\
\text { decreased co-determination of the employees or the } \\
\text { increase of less protected work conditions [19]. }\end{array}$ & $\begin{array}{l}\text { Abolishment of the } \\
\text { legal amount of work } \\
\text { hours in minijobs }{ }^{1}[21]\end{array}$ \\
\hline Stability & $\begin{array}{l}\text { Creating a more stable order situation and thus a stable } \\
\text { position at the market can be a goal of } \\
\text { flexibilisation. This can be achieved by reactive as well } \\
\text { as proactive measures. }\end{array}$ & Ability to adjust \\
\hline Growth & $\begin{array}{l}\text { Economic growth can also be a proactive goal of } \\
\text { flexibilisation. }\end{array}$ & $\begin{array}{l}\text { Handling new } \\
\text { markets. }\end{array}$ \\
\hline
\end{tabular}

${ }^{1}$ Minijobs are a special kind of job in Germany. They are low-paid or short-term and are associated with special legal regulations.

\subsection{Potential Measures to Increase Flexibility in SMEs}

Textbooks of industrial psychology and business studies give an abundance of measures which can be taken to achieve flexibilisation. However, most of these approaches concern big, manufacturing companies. A minimum amount of employees, technical supplies and of resources are necessary. For SMEs with 250 or less employees, these approaches are of little or no use. In the last couple of years, more and more attention has been paid to the economic importance of SMEs and a couple of approaches to achieve flexibility in SMEs, tailored to businesses of small and medium size, have been developed. An overview can be found at Debitz et al. [22]. Table 2 outlines these potential approaches to achieve flexibility in SMEs. 
Table 2: Potential measures to increase flexibility according to Debitz et al. [22].

\begin{tabular}{|c|c|c|}
\hline Subject area & Category & Example of measures \\
\hline \multirow{6}{*}{ Work force } & \multirow{2}{*}{ Qualification } & (i) Instruction of trainees \\
\hline & & (ii) advanced training on the job \\
\hline & \multirow[t]{2}{*}{ Employment } & (i) Creating new jobs \\
\hline & & (ii) Part-time employment \\
\hline & \multirow{2}{*}{ Hiring/selection of personnel } & (i) employment ads \\
\hline & & (ii) Accessment Center \\
\hline \multirow{8}{*}{ Technology } & \multirow{2}{*}{ Quality } & (i) Certification, for example ISO 9000 \\
\hline & & (ii) Standards \\
\hline & \multirow{2}{*}{ Software } & (i) ERP-systems \\
\hline & & (ii) $\mathrm{CAD}$ \\
\hline & \multirow{2}{*}{ Hardware } & (i) Machines \\
\hline & & (ii) Vehicles \\
\hline & \multirow{2}{*}{$\begin{array}{l}\text { Internet, networks, } \\
\text { telecommunication }\end{array}$} & (i) Mobile internet \\
\hline & & (ii) Intranet/joint server \\
\hline \multirow{12}{*}{ Organisation } & \multirow{2}{*}{ Finances } & (i) Performance-related payment \\
\hline & & (ii) Investments \\
\hline & \multirow{2}{*}{ Work schedules } & (i) Flexitime \\
\hline & & (ii) Shift work \\
\hline & \multirow{2}{*}{ Organisational structure of work } & (i) Working in small groups \\
\hline & & (ii) Establishing of responsibilites \\
\hline & \multirow[t]{2}{*}{ Structure of company } & (i) Profit center \\
\hline & & (ii) Changes in hierarchical structure \\
\hline & \multirow{2}{*}{ Production } & (i) stock production \\
\hline & & (ii) Changes in depth of production \\
\hline & \multirow{2}{*}{ Networking } & (i) Networking between companies \\
\hline & & (ii) Product development together with the customers \\
\hline
\end{tabular}

\section{Questions}

Since findings on stability and flexibility in SMEs are incomplete in a lot of areas and, thus, it was not possible to infer well-based hypotheses, an explorative approach was chosen.

\subsection{Which Goals Do the Interviewed CEOs Formulate Concerning Flexibility of Their Company?}

Setting goals is an important requirement for a strategic approach when dealing with needs of flexibility. Therefore we wanted to know whether at all and which goals concerning flexibility are formulated in our sample and what contents these goals refer to.

\subsection{Which Measures to Increase Flexibility Do CEOs Know about and Which Ones Are Unknown to Them?}

To increase flexibility, companies can only use measures, which they know about. A lack of knowledge can thus restrain flexibilisation. Therefore, we wanted to analyse the knowledge of CEOs on different measures. 
Table 3: Samples of enterprises: first interviews $\left(t_{1}\right)$; second interviews $\left(t_{2}\right)$.

\begin{tabular}{lcccc}
\hline $\mathrm{t}_{1}$ & $\begin{array}{c}\text { Manufacturing and } \\
\text { processing } \\
\text { industries }\end{array}$ & Service providers & Trading companies & Sum \\
\hline Micro enterprises & 2 & 7 & 5 & $\mathbf{1 4}$ \\
Small enterprises & 13 & 10 & 2 & $\mathbf{2 5}$ \\
Medium-sized enterprises & 5 & 4 & 0 & $\mathbf{9}$ \\
\hline Sum & $\mathbf{2 0}$ & $\mathbf{2 1}$ & Trading companies & Sum \\
\hline $\mathrm{t}_{2}$ & Manufacturing and & Service providers & $\mathbf{7}$ \\
\hline Micro enterprises & industries & 7 & 1 & $\mathbf{8}$ \\
Small enterprises & 0 & 6 & 0 & $\mathbf{1 4}$ \\
Medium-sized enterprises & 7 & 0 & $\mathbf{2}$ & $\mathbf{5}$ \\
\hline Sum & 5 & $\mathbf{1 3}$ & & $\mathbf{2 7}$ \\
\hline
\end{tabular}

\subsection{Which Measures Do Companies Use When Dealing with Needs for Flexibility?}

Referring on the analysis of Debitz et al. [22] concerning measures to increase flexibility, we were interested to what extend the companies actually use these strategies. Further we analysed, wether the companies use strategies which are not yet described in the literature, that is, strategies which were customized for the situation of the company and which are unique to the size and sector within our sample (company specific measures).

\subsection{Which Obstacles Do Companies Face When Implementing Measures to Increase Flexibility?}

As mentioned, SMEs might show specific characteristics which are of importance for the implementation of measures enhancing flexibility. Therefore, we wanted to know which obstacles the companies have to cope with in order to implement measures to increase flexibility.

\section{Methods}

\subsection{Sample}

We interviewed 48 CEOs of small and middle-sized German enterprises. After an average of 13 months 27 CEOs could be interviewed again to identify changes in the assignment of measures to cope with needs for flexibility. The sample was obtained by convenience sampling.

Table 3 offers the numbers of micro, small and medium-sized companies analysed (EU definition, [23]).

\subsection{Data Collection}

Based on a broad analyses of the literature [22] we developed a questionnaire, recording which measures to increase flexibility were known and applied by the companies. It offered 
Table 4: Goals concerning flexibility mentioned by the CEOs. $N=48$ CEOs; 72 goals (100\%).

\begin{tabular}{|c|c|c|c|c|c|c|c|c|c|c|c|c|c|c|}
\hline \multirow[b]{2}{*}{ 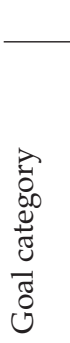 } & \multicolumn{3}{|c|}{ Personnel } & \multicolumn{2}{|c|}{ Technology } & \multicolumn{3}{|c|}{ Organisation } & \multicolumn{5}{|c|}{ Market } & \multirow[b]{2}{*}{ 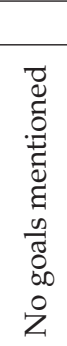 } \\
\hline & 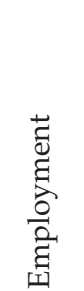 & 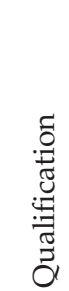 & 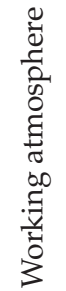 & 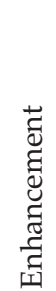 & 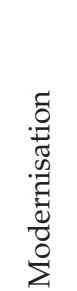 & 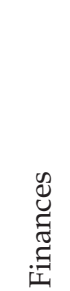 & 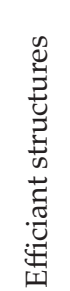 & 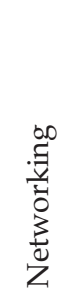 & $\begin{array}{l}\text { F } \\
\text { 芳 } \\
\text { 岂 }\end{array}$ & 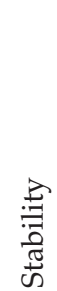 & 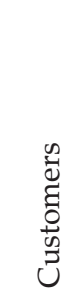 & 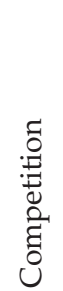 & 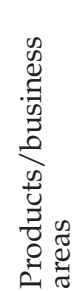 & \\
\hline$\%$ & 10,7 & 13,3 & 1,3 & 2,7 & 1,3 & 10,7 & 8,0 & 1,3 & 10,7 & 6,7 & 14,7 & 9,3 & 9,3 & 16,7 \\
\hline
\end{tabular}

83 measures to increase flexibility with possible answers ranging from $1=$ "unknown", $2=$ "known, but not applied", $3=$ "implementation intended" to $4=$ "applied". A short explanation was added to each measure in order to ensure correct responses. Moreover we asked the question whether the companies are using strategies to increase flexibility, which were described not in the literature yet and, thus, our offered list.

Furthermore we developed interview guidelines, in order to identify the challenges that $\mathrm{CEOs} \mathrm{perceived} \mathrm{concerning} \mathrm{flexibility,} \mathrm{their} \mathrm{goals} \mathrm{concerning} \mathrm{flexibility} \mathrm{and} \mathrm{the} \mathrm{measures}$ applied, including preconditions and obstacles, as to personnel, technology and organisation.

For each company, interview and questionnaire data were examined in order to find out whether any measures were implemented or planned at $t_{1}$. If so, these measures were incorporated in the manual for the second interview at $t_{2}$, in order to find out, if they actually were implemented in the meantime and with what results, or which obstacles prevented the implementation so far.

\subsection{Data Analysis}

The standard procedure for analysing interview data is the qualitative content analysis by Mayring [24]. Following this procedure we paraphrased and reduced the interview data. We discussed and developed a set of categories within our research group. The resulting interrater reliability (Cohen's Kappa 0.7) is sufficiently high.

Measures which had not yet been described in the literature were marked and included in the guidelines for the second interview.

In order to prepare the entire dataset for statistical analysis, we compared and integrated the questionnaire and interview data. In a second step inferential statistics were applied to identify differences between the subgroups of the sample. Due to the small size of the groups, we had to use the nonparametric chi-squared test.

\section{Results}

\subsection{Which Goals Do the CEOs Report Concerning Flexibility?}

Almost $17 \%$ of the interviewees did not mention any goals concerning flexibility even though they were asked about them.

Most goals concerning flexibility mentioned are customer related (see Table 4). Mostly, these goals are about improving the service as well as finding a specific niche or unique selling 
position. The second frequent category mentioned was in work force issues. In this context, the goal of keeping employees with the company was especially prominent. On the one hand this means preventing skilled workers from leaving, on the other hand trying to avoid layoffs, even in times of economic crisis.

Goals concerning qualification and growth, for example growth in sales or new subsidiaries, as well as financial goals, rank third. These include "maintaining solvency", "increasing equity" and "reducing costs."

\subsection{Which Measures to Increase Flexibility Do CEOs Know about and Which Ones Are Unknown to Them?}

The interviewed CEOs knew most of the measures listed in the questionnaire. However, there are differences between sectors and business size.

The answer "unknown" occurred for 59 of the 83 measures at $t_{1}$. In order to identify essential knowledge gaps, Table 5 offers measures, which at least $20 \%$ of the CEOs did not know about and shows the relevant differences concerning company size and sector.

Knowledge gaps exist especially concerning technical and organisational measures. There are only minor differences between companies of different size and sector on average for all measures combined. As to the individual measures due to small sample sizes significant differences only exist in two cases comparing micro- and small enterprises.

\subsection{Which Measures Do the Companies Apply?}

The CEOs mentioned a total of 551 measures in the categories of work force, technology, organisation and the additionally introduced category of market. Table 6 shows the distribution within the different categories.

More than one-third (176, about 34\%) of all measures can be assigned to measures concerning workforce. This includes measures of employment such as hiring, layoffs, shortterm, and part-time jobs, temporary employment as well as qualification and selection of personnel. About $13 \%$ of all measures can be assigned to marketing and sales. It comprises different strategies such as running a homepage, placing ads in different kinds of media, presentations of products as well as social media, that is, online services such as Twitter or Facebook.

Differences in the number of implemented measures only exist between micro enterprises and small as well as medium-sized ones. There are no significant differences between small- and medium-sized enterprises or between companies of different sectors (Table 7).

Company specific measures, which could not be found in the literature were identified in almost $40 \%$ of the interviewed companies. There is an equal amount of company-specific measures in small and medium-sized enterprises, whereas only one micro enterprise used measures that are tailored to its specific needs. These measures mainly are focused on flexible allocation of personnel—provided that the personnel was highly and appropriately qualified - as well as on the cooperation with partners offering mutual benefits.

An example of a company-specific measure is the photographic documentation of every order on every day in a small enterprise of the manufacturing and processing sector. The employees were equipped with digital cameras and the pictures were added to a database at the end of the day. Despite the time and effort to run this database, the CEO 
Table 5: Measures, which at least $20 \%$ of the interviewed CEOs rated as "unknown" as well as the corresponding differences regarding company size and sector. ${ }^{*} P \leq .05$. All information is given in $\%$.

\begin{tabular}{|c|c|c|c|c|c|c|c|}
\hline & Total & $\begin{array}{c}\text { Micro } \\
\text { enterprises }\end{array}$ & $\begin{array}{c}\text { Small } \\
\text { enterprises }\end{array}$ & $\begin{array}{l}\text { Medium- } \\
\text { sized } \\
\text { enterprises }\end{array}$ & $\begin{array}{c}\text { Manufacturing } \\
\text { and processing } \\
\text { industries }\end{array}$ & $\begin{array}{l}\text { Service } \\
\text { providers }\end{array}$ & $\begin{array}{l}\text { Trading } \\
\text { companies }\end{array}$ \\
\hline \multicolumn{8}{|l|}{ Technology } \\
\hline $\begin{array}{l}\text { Enterprise resource } \\
\text { planning system (ERP) }\end{array}$ & 26 & $54^{*}$ & 13 & 14 & 11 & 28 & 67 \\
\hline $\begin{array}{l}\text { Supply chain } \\
\text { management system } \\
\text { (SCM) }\end{array}$ & 20 & 23 & 13 & 38 & 25 & 17 & 17 \\
\hline $\begin{array}{l}\text { Virtual Technology } \\
\text { network }\end{array}$ & 23 & 23 & 22 & 25 & 32 & 5 & 50 \\
\hline \multicolumn{8}{|l|}{ Organisation } \\
\hline $\begin{array}{l}\text { Administration tool } \\
\text { "Ampelkonto"2 }\end{array}$ & 51 & 64 & 46 & 44 & 60 & 45 & 43 \\
\hline Part-time on-call work & 26 & 21 & 22 & 40 & 35 & 14 & 14 \\
\hline Job splitting & 23 & 9 & 21 & 17 & 25 & 5 & 29 \\
\hline Sabbaticals & 23 & 21 & 21 & 33 & 35 & 1 & 40 \\
\hline $\begin{array}{l}\text { Profit } \\
\text { center-associations of } \\
\text { employers within one } \\
\text { industry sector }\end{array}$ & 20 & $44^{*}$ & 8 & 13 & 2 & 13 & 33 \\
\hline Employer grouping & 28 & 33 & 29 & 17 & 31 & 24 & 33 \\
\hline Average & & 32 & 22 & 27 & 28 & 17 & 36 \\
\hline
\end{tabular}

${ }^{2}$ Web-application for the easy administration of flexible individual working time.

Table 6: Distribution of measures to increase flexibility reported in the interview. $N=48$ CEOs; 511 overall mentions, percentages.

\begin{tabular}{|c|c|c|c|c|c|c|c|c|c|c|c|c|c|c|c|c|}
\hline \multirow[b]{2}{*}{ 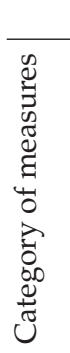 } & \multicolumn{3}{|c|}{ Personnel } & \multicolumn{4}{|c|}{ Technology } & \multicolumn{6}{|c|}{ Organisation } & \multicolumn{3}{|c|}{ Market } \\
\hline & 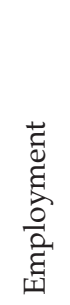 & 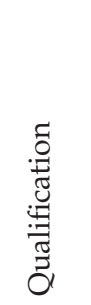 & 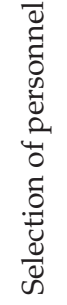 & 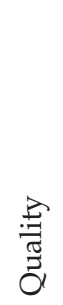 & 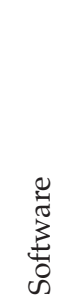 & 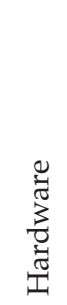 & 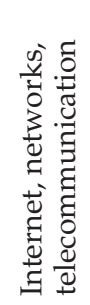 & 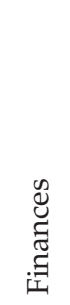 & 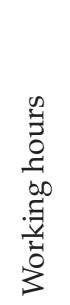 & 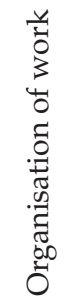 & 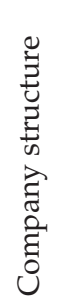 & $\begin{array}{l}\tilde{0} \\
.0 \\
0 \\
\tilde{Z} \\
0 \\
0\end{array}$ & $\begin{array}{l}0.0 \\
0 \\
0 \\
0 \\
3 \\
0 \\
0\end{array}$ & 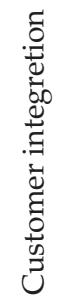 & 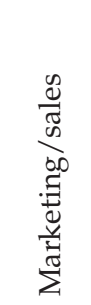 & 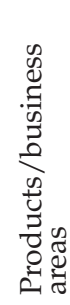 \\
\hline$\%$ & 15,7 & 16,4 & 1,4 & 1,0 & 7,2 & 6,8 & 4,5 & 4,7 & 7,2 & 3,9 & 2,9 & 1,6 & 5,5 & 4,3 & 13,3 & 3,5 \\
\hline
\end{tabular}

Table 7: Differences in the number of implemented measures to increase flexibility between companies of different size.

\begin{tabular}{lccc}
\hline & Mean value & Minimum & Maximum \\
\hline Micro enterprises & $22^{* * / * *}$ & 10 & 38 \\
Small enterprises & $38^{-}$ & 19 & 52 \\
Medium-sized enterprises & 39 & 26 & 53 \\
\hline
\end{tabular}


reported clear advantages of this approach: every employee could access the data and continue the work or explain it to the costumer. Employees could easily fill in for each other. Moreover, a $\mathrm{CD}$ with the pictures was created after finishing the order and given to the customer as an additional service. According to the CEO, these two aspects gave the company a clear advantage over its competitors.

Another example is the extensive flexibilisation of work schedules of a small serviceproviding company. Based on mutual trust, the employees were given freedom concerning their work schedules including daily working hours and annual leave in an individual and flexible manner. In return, employees worked longer if needed, including the late evening and weekends. Aside from positive effects on work-life balance and satisfaction, the CEO had also noticed a high adherence to delivery dates as well as the ability of the company to react quickly to short-notice demands of customers.

\subsection{Which Obstacles Do Companies Face in Implementing Measures to Increase Flexibility?}

The CEOs perceived obstacles to the implementation of measures intended to increase flexibility in about $40 \%$ of their reported measures. These obstacles may result from difficulties within the companies themselves, from external ones or from such resulting from overlapping sources (Table 8 ). The majority are internal obstacles.

The lack of financial and time resources as well as insufficient qualification of the employees were an especially prevalent answer. Obstacles outside of the company itself concerned mostly the job and vocational training market, the demand and order situation as well as the quality of services of others. The latter referred mostly to lack of specification of advanced training offers for the needs of the SMEs as well as the lack of tailored ITsolutions. Moreover, obstacles with overlapping sources, were identified. This holds for example, if frequently changing temporary workers, whose qualifications and job experience often do not match the requirements of the company, are to be integrated into the company. Other problems of this kind refer to the fit with external partners, mainly when exchanging personnel in order to overcome deficient use of capacity.

Finally, we examined to what extend the companies implemented measures, which they planned at $t_{1}$, during the period of investigation. For 20 measures the information was available for both dates of investigation. Only $25 \%$ of these measures were implemented at $t_{2}$ because of missing prerequisites.

\section{Discussion}

\subsection{Goals Concerning Flexibility}

A substantial part of the interviewed CEOs did not report any goals concerning flexibility for their companies. In these companies, a strategic approach, which proactively directs measures to intended goals, does not exist. This may result in a competitive disadvantage.

The most frequently reported goals concerning flexibility of the surveyed SMEs are goals concerning the integration of customers in product development and details of manufacturing, and goals as to a qualified, flexible, and loyal staff. 
Table 8: Obstacles to flexibilisation mentioned by the CEOs. The percentages show the share of implemented measures $(n=511)$ in which the obstacles were perceived by the CEOs.

(a)

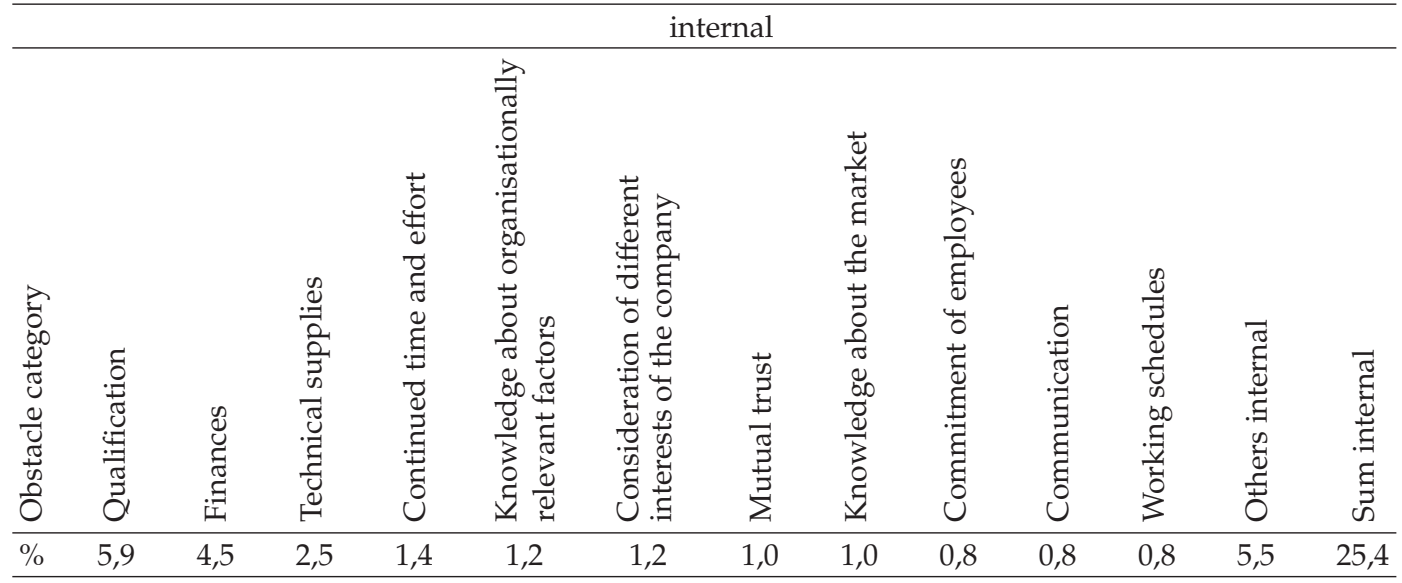

(b)

\begin{tabular}{|c|c|c|c|c|c|c|c|c|c|c|c|}
\hline \multicolumn{5}{|c|}{ Overlapping } & \multicolumn{7}{|c|}{ External } \\
\hline $\begin{array}{l}\text { Dे } \\
0 \\
0 \\
0 \\
0 \\
0 \\
0 \\
0 \\
\frac{\pi}{0} \\
0 \\
0\end{array}$ & 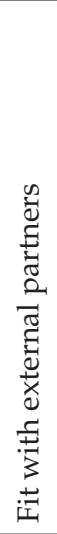 & 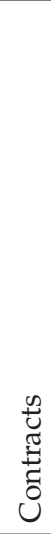 & 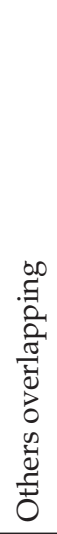 & 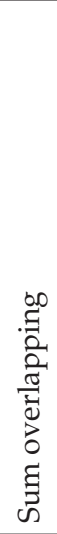 & 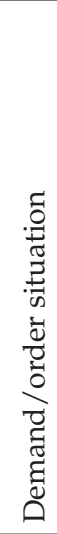 & 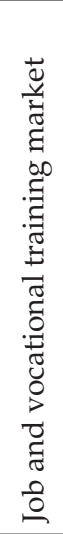 & 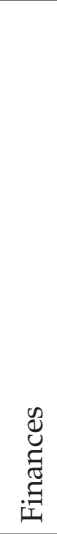 & 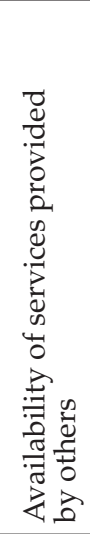 & 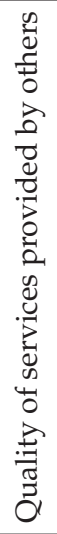 & 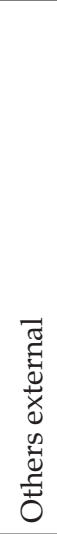 & 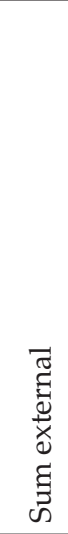 \\
\hline$\%$ & 2,0 & 0,6 & 1,4 & 3,9 & 4,9 & 1,8 & 0,8 & 0,8 & 0,6 & 1,6 & 10,4 \\
\hline
\end{tabular}

\subsection{Knowledge about Measures}

Considerable differences concerning the knowledge about measures as well as their implementation can be observed between companies of different size. Knowledge gaps are mainly observed as to technology and organisation. There are considerable differences concerning the individual measures for companies of different size and different sectors. However, because of the small sample size, these differences are rarely of statistical significance.

The fact that a substantial part of CEOs, especially of small and microenterprises, are skilled workers, but did not have any explicit management training, might be the reason for the existing lack of knowledge about approaches to increase flexibility. Moreover, there is also a lack of affordable offers, which—for example by structuring the training so that it contains different modules-make a qualification tailored to the needs of managers in German SMEs possible. 


\subsection{Applied Measures}

The investigated companies use measures concerning work force, technology, and organisation as well as market, which was not accounted for originally, but was added into the examination due to the high number of relevant measures mentioned.

Differences concerning the implementation of measures were observed mainly depending on company size. This holds especially for company specific measures, which exist in companies of small- and medium-sized, but not in microenterprises with limited managerial resources.

\subsection{Perceived Obstacles}

Obstacles to flexibilisation could be identified on multiple levels. On one hand, there are external obstacles such as a shortage of skilled workers and trainees at the labour market or demands by customers on short notice. Companies have little or no control on these variables.

On the other hand, we identified a number of obstacles within the companies themselves, which point at the potential of flexibilisation within the investigated SMEs. For example the inability to cope with needs for flexibility in a strategic way is due to the lack of self-set goals and is to be interpreted as an obstacle to flexibilisation. Additionally the majority of the interviewed CEOs were aware of the fact, that flexibility can not be implemented without participation of the employees. They mentioned lack of communication and trust as well as lacking commitment of their employees as obstacles to the implementation of measures. Thus, there is a need for change management, which supports enterprises in the endeavour of balancing flexibility and stability. However, the fact that this was not mentioned as one of the goals hints that either the companies underestimate the importance of systematic change management or that they assume a lack of appropriate resources for efficiently supervised change on their part. In this regard, the fact that CEOs often had no time to implement new measures due to more urgent tasks, was especially prominent. Finally, the lack of knowledge about potential measures to increase flexibility can pose an obstacle, because informed and strategic decisions during the process of flexibilisation are based just on this knowledge.

\subsection{Implications}

Systematic approaches to increase flexibility which may be integrated into the real-life process of German SMEs without additional expenditure are lacking. A practical tool, might be helpful.

It has been shown that some SMEs are not able to implement sustainable participative change management on their own due to their organisational size and financial resources. Thus, a tool which is available to the companies in a tailored fashion which takes their limited resources into consideration, should include the following parts:

(a) information about the individual steps of developing a strategy, which are presented in a way that makes them directly replicable to the own company,

(b) information about collateral change management on all levels that are affected by the changes, 
(c) information about potential measures to increase flexibility, their advantages and disadvantages as well as possible ways of combining them and the reciprocal effects of the different measures.

These parts should be interlaced in a way which immediately informs the user at what point he or she needs to consider which aspects of which area, for example, at which point he should include the employees to which extent.

The development of such a tool should be carried out interdisciplinary. At the same time with regard to acceptance and usability an appealing and intuitively usable user interface plays a major role. One approach of implementation is an online tool box [25], which systemises the existing findings and makes them available to interested managers in a practically applicable way. The flexibility measures provided in the tool box are configured especially for German SME's CEOs and are explicitly recommended to being applied in a participatory way. Measures concerning the fields of personnel, technology, organisation and market are briefly described using the categories intent, conditions, obstacles, effects, possible combinations with other measures, criteria for evaluation as well as relevant literature. As the evaluation of the tool box is carried out currently, only little can be said about criteria such as usability and acceptance. However first responses to an earlier printed version show that many CEOs perceive the centralised presentation of possible flexibility measures as timesaving and helpful.

\subsection{Limitations and Further Research}

A study testing hypotheses based on the present findings in order to replicate these findings for a greater sample would be desirable.

In future studies, the point of view of the employees should be considered, too, and the respective results should be made available to the managers. Especially a tool which facilitates a strategic development of the processes in SMEs should not ignore the point of view of employees. The economic change, the associated flexibilisation, and the possibly produced uncertainty of private and professional life poses new and bigger challenges for employees now than in the past. Inspite of the scientific findings about the consequences of increasing flexibilisation on physical and mental health, performance, and satisfaction of employees the effects of different aspects of flexibility are not yet known and need to be investigated.

\section{References}

[1] B. Kaluza and T. Blecker, Wettbewerbsstrategien-Markt-und ressourcenorientierte Sicht der strategischen Führung. Konzept-Gestaltungsfelder-Umsetzungen, TCW, Munich, Germany, 2000.

[2] G. Fischer, V. Dahms, S. Bechmann, Bilger, and F. Frei, "Langfristig handeln, Mangel vermeiden: Betriebliche Strategien zur Deckung des Fachkräftebedarfs," Ergebnisse des IAB-Betriebspanels 2007, IAB Forschungsbericht 3/2008, 2008, http:/ /doku.iab.de/forschungsbericht/2008/fb0308.pdf.

[3] Bundesagentur für Arbeit, "Positive Entwicklung auf dem Ausbildungsmarkt setzt sich fort_Paktpartner engagieren sich verstärkt für den Fachkräftenachwuchs," 2011, http:/ / www.arbeitsagentur.de/zentralerContent/Pressemeldungen/2011/Presse-11-067,mode=print.html.

[4] A. Werner and R. Kay, "Arbeitgeberattraktivität: Sind KMU im Nachteil gegenüber Großunternehmen? Presentation," IfM, Bonn, Germany, 2008, http://www.ifm-bonn.org/assets/documents/Werner_Kay30-10-08.pdf. 
[5] E. Müller, "Erfolgsfaktor Flexibilität. Forschungsergebnisse und Praxiserfahrungen aus dem BMBFProjekt," Fachinfo 02/2011, RKW Deutschland, Berlin, Germany, 2011, http://balanceonline.org/ system/files/private/KMUflex_FACHINFO_1_druck.pdf.

[6] Institut für Mittelstandforschung, "Schlüsselzahlen des Mittelstands in Deutschland gemäß der KMUDefinition der EU-Kommission," 2008, http://www.ifm-bonn.org/assets/documents/SZ-Unt\&Ums\& Besch_2004-2009_D_KMU_nach_EU-Def.pdf.

[7] S. Schoenwald, "KfW-ifo-Mittelstandsbarometer: Dezember 2011," 2012, http:/ /www.kfw.de/kfw / de/I/II/Download_Center/Fachthemen/Research/PDF-Dokumente_Mittelstandsbarometer/KfWifo-Mittelstandsbarometer_2011-12.pdf.

[8] M. Saatmann and K. I. Voigt, "Begriffsbestimmung Flexibilität und Adaptivität," Arbeitspapier FlexLog, 01/2005, 2005.

[9] M. A. Hitt, B. W. Keats, and S. M. DeMarie, "Navigating in the new competitive landscape: building strategic flexibility and competitive advantage in the 21st century," Academy of Management Executive, vol. 12, no. 4, pp. 22-42, 1998.

[10] Brockhaus Enzyklopädie Online, Stabilität, 2010, http://www.brockhaus-enzyklopaedie.de/be21 _article.php.

[11] Brockhaus Enzyklopädie Online, Strategie, 2010, http://www.brockhaus-enzyklopaedie.de/be21 -article.php.

[12] D. Boch and and B. Constanzo, "Change-Management-Begleitkonzept für einen nachhaltigen Veränderungsrozess," in Flexible Arbeitswelten: Handlungsfelder, Erfahrungen und Praxisbeispiele aus dem Flexible-Office-Netzwerk, S. Zinser, Ed., vdf Hochschulverlag, Zurich, Switzerland, 2004.

[13] F. Weiler, Soziale Kompetenz und Management, Books on Demand GmbH, Norderstedt, Germany, 2010.

[14] G. Schuh, Change Management-Prozesse strategiekonform gestalten, Springer, Heidelberg, Germany, 2006.

[15] H. Stahl, "Führungskräfte als Mentoren," in Erfolgreich im Schatten der Großen. Wettbewerbsvorteile für kleine und mittlere Unternehmen, H. Stahl, H. Hinterhuber, and M. Bank, Eds., pp. 65-82, Erich Schmidt, Berlin, Germany, 2003.

[16] C. Deuringer, Organisation und Change Management. Ein ganzheitlicher Strukturansatz zur Förderung organisationaler Flexibilität, Deutscher Universitäts, Wiesbaden, Germany, 2000.

[17] T. Lauer, Change Management. Grundlagen und Erfolgsfaktoren, Springer, Heidelberg, Germany, 2010.

[18] S. Kinkel, G. Lay, and A. Hunter, "Mehr Flexibilität durch Organisation: Stellenwert strategischer Flexibilitätsziele, Nutzung organisatorischer Befähiger und Erreichbarkeit von Flexibilitätszuwächsen," Mitteilungen aus der ISI-Erhebung zur Modernisierung der Produktion Nr. 42, Fraunhofer ISI, Karlsruhe, Germany, 2007.

[19] J. Flecker, "Interne Flexibilisierung-von der Humanisierungsvermutung zum Risikobefund," in Flexicurity. Die Bindung von Sicherheit an Flexibilität, M. Kronauer and G. Linne, Eds., Edition Sigma, Berlin, Germany, 2005.

[20] P. Totterdill, Developing New Forms of Work Organisation: The Role of the Main Actors, The Work Institute, Nottingham, UK, 2002.

[21] Bundesministerium für Arbeit und Soziales, 400-Euro-Mini-Jobs/Geringfügige Beschäftigung, 2007, http:/ / www.bmas.de/DE/Themen/Soziale-Sicherung/400-Euro-Mini-Jobs/400-euro-mini-jobsgeringfuegige-beschaeftigung.html.

[22] U. Debitz, U. Pietrzyk, and K. Roitzsch, Stabilität durch systematische Selbstveränderung. Flexibilisierungsmaßnahmen für KMU-Toolbox 1.1, Technische Universität Dresden, Dresden, Germany, 2010.

[23] European Commission, "The new SME definition," User guide and model declaration, 2005, http:/ / ec.europa.eu/enterprise/policies/sme/files/sme_definition/sme_user_guide_en.pdf.

[24] P. Mayring, Einführung in die qualitative Sozialforschung, Beltz, Weinheim und Basel, Germany, 2002.

[25] http://www.flexikonline.de. 


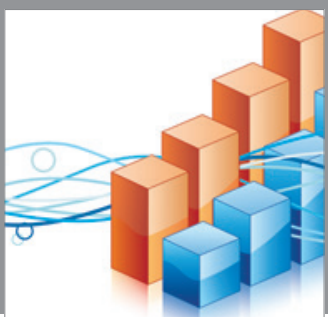

Advances in

Operations Research

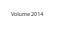

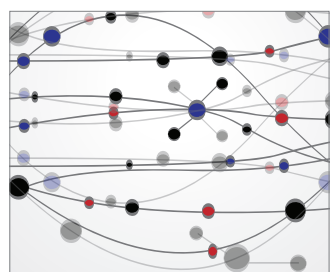

\section{The Scientific} World Journal
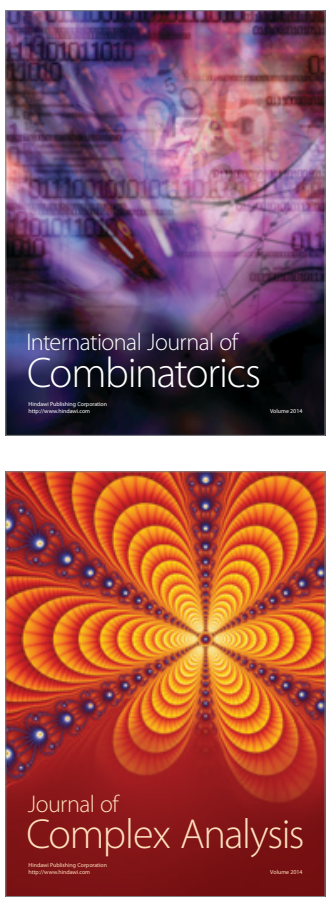

International Journal of

Mathematics and

Mathematical

Sciences
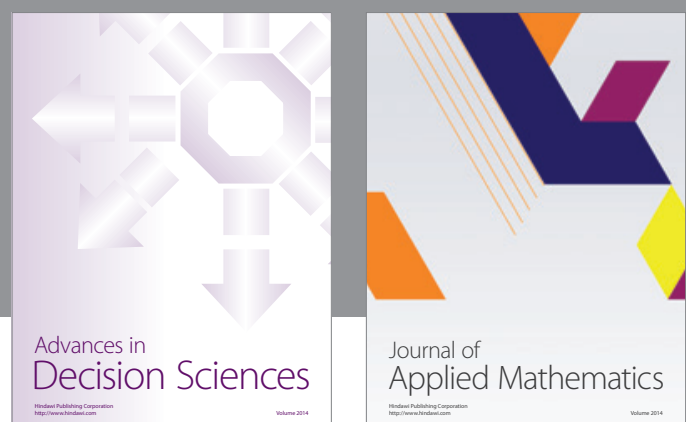

Journal of

Applied Mathematics
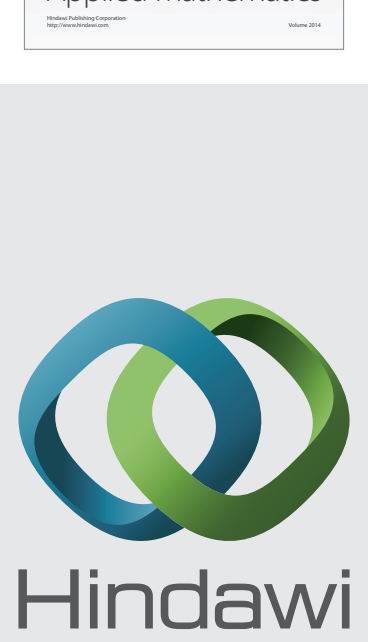

Submit your manuscripts at http://www.hindawi.com
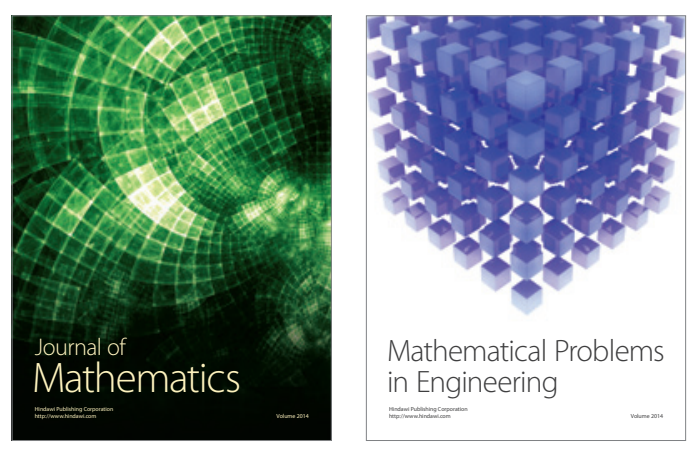

Mathematical Problems in Engineering
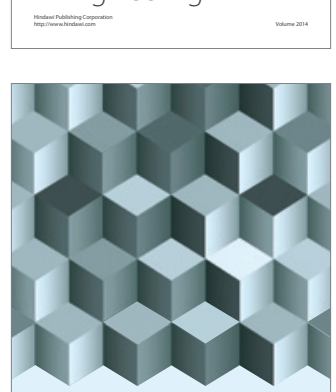

Journal of

Function Spaces
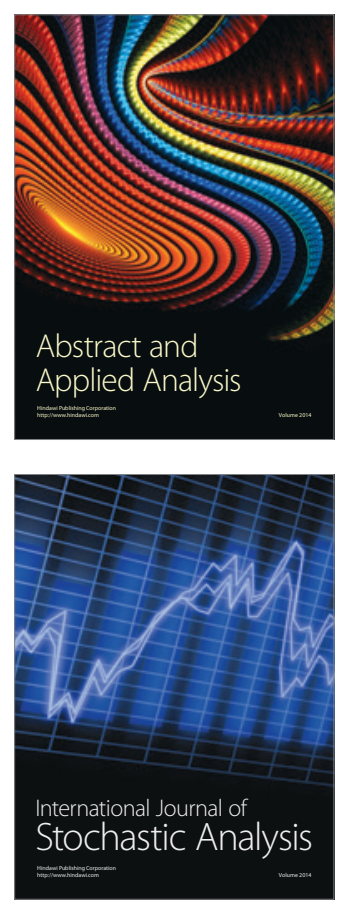

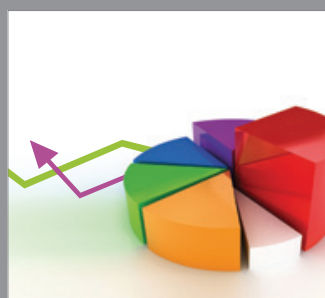

ournal of

Probability and Statistics

Promensencen
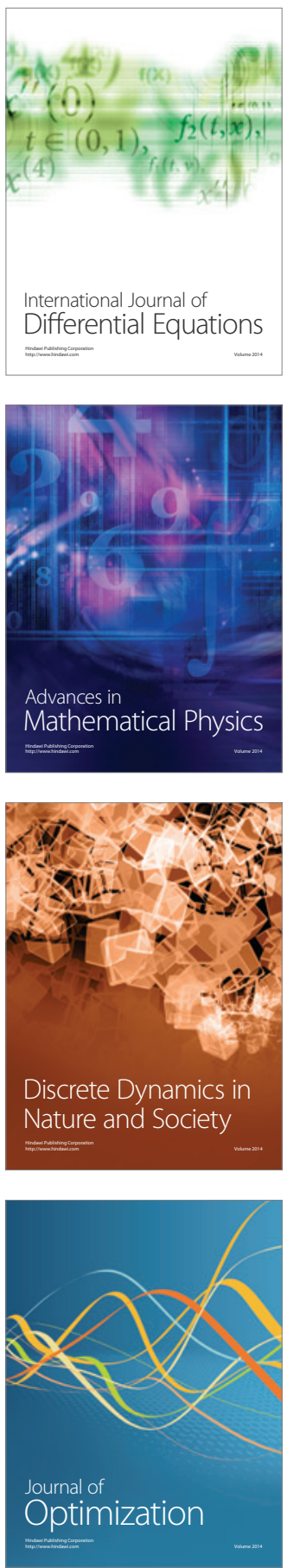